\title{
Interplay of National Interest and Ideologies with Global Frame of War on Terror: Coverage of Tiananmen Attack in Chinese, Thai, and US Newspapers
}

\author{
Muhammad Shahzad Yousaf \\ School of Journalism and Information Communication, Huazhong University of Science and Technology, Wuhan, China \\ Email: shahzadmehr@live.com
}

How to cite this paper: Yousaf, M. S. (2019). Interplay of National Interest and Ideologies with Global Frame of War on Terror: Coverage of Tiananmen Attack in Chinese, Thai, and US Newspapers. Advances in Journalism and Communication, 7, 129-141. https://doi.org/10.4236/ajc.2019.74009

Received: November 15, 2019

Accepted: December 20, 2019

Published: December 23, 2019

Copyright () 2019 by author(s) and Scientific Research Publishing Inc. This work is licensed under the Creative Commons Attribution International License (CC BY 4.0).

http://creativecommons.org/licenses/by/4.0/ (c) (i) Open Access

\begin{abstract}
Chinese, Thai, and US media reports about the 10-28 Tiananmen attack were used as data to study news frames and understand how frames are constructed nationally, regionally, and globally. How these frames are borrowed and used for the sake of gaining approval and how global "war on terror" frame is used without much criticism. Study used one-week news reports about the 10-28 Tiananmen attack in 2013 from Asia News Monitor, China Daily, New York Times, and Wall Street Journal for analysis. It was found that national interest and ideologies play an important part in frame construction while globalized frames are employed to gain approval from rest of the world and become part of "us" and outcast "them". US newspapers use analogies completely irrelevant to attack and try to use this even as a reminder for reader that Tiananmen square is historically famous for pro-democracy protests. Chinese newspapers do not employ global "war on terror": frame to portray the 10-28 attack and avoid connecting it to global terrorism.
\end{abstract}

\section{Keywords}

Framing, Analogies, War on Terror, Globalization, NYT, WSJ, Construction of Framing

\section{Introduction}

According to Entman's (1993) definition of framing, it is process of selection and salience so, it is important to study how different aspects of a reality are selected/constructed and made salient in order to further a specific understanding of the reality. "War on Terror", for example, was a carefully selected frame by 
Bush administration and it served the purpose of the Administration to rally people behind exporting war (Reese, 2010) to foreign lands and sending troops abroad. Framing, according to Entman (1993), is process to make certain pieces of information "prominent", i.e. through repetition, in order for the audiences to make them store those prominent aspects of reality in their memory. Journalists play a role in flow of information and constructing reality for the public. Although this construction can be conscious or subconscious (D'Angelo \& Kuypers, 2010), Gerhards \& Schäfer (2014) argue that there are three ways, in which terrorism news are framed: 1) national, 2) regional, and 3) global.

China has been cautious to support "war on terror(ism)" apart from the instances when it suited its own national interest (Rahman, 2012). Authors like Du \& Li (2017) have also found out that press systems in different countries especially China and US employ different framing strategies aligning with their ideologies and national interest. This study explores press coverage of the 10-28 Tiananmen Square attack among China, Thailand, and US newspapers and explores how frames flow from national to regional to global context and vice versa taking a varied direction from previous studies i.e. that of ( $\mathrm{Du} \& \mathrm{Li}, 2017$; Fahmy, 2010; Rahman, 2012). This study aims to unveil how frames flow from China to US (national to global) and from US to China (global to domestic).

On the afternoon of October 28, 2013, three offenders coming from same family being a husband and wife and mother ploughed their vehicle through the pedestrians in Tiananmen Square. Vehicle was filled with gasoline and a white flag with black writing on it was spotted by the witnesses. This incident caused in five including three perpetrators and two tourists dead and other 38 injured (Ranran, 2013). This incident was reported by Chinese, regional, and international media outlets. Here, we study the frames constructed by Chinese, Thai, and US media in order to determine how frames were constructed and borrowed from each other. Global "war on terror" frame is usually employed by media around the world when reporting about terror incident (Reese, 2010). So, here we study how Chinese media has employed this frame to make this incident relevant to global war on terror. The study examines depth of coverage, "episodic" or "thematic" to determine how it was linked or not to global terrorism and how historical contexts "analogies" have been used to construct the incident. Historical analogies are used by newspaper to provide "context" for the audiences to frame the reported incident in a specific way (Axelrod \& Forster, 2017). This study will examine how analogies have been used by Asian and US newspaper and how it has helped to construct the frames in a specific way. Blame/victimization frames along with evaluation of the incident provided by newspaper are also studied to determine the stances of newspapers from different countries about the 10-28 Beijing attack.

\section{Theoretical Framework}

The theoretical framework developed for this paper indicates that terror events 
are simplified through news frames and these frames prioritize and structure the narrative flow of events (Norris, Kern, \& Just, 2003). Although framing as a theory of media effects has three distinctive but entwined paradigms being, cognitive, constructive, and critical, we are concerned here with second and third paradigms of construction of frames and critical approach to it in this study. Construction approach of framing terrorism suggests that there are three different levels, at which terrorism is framed (Gerhards \& Schäfer, 2014). Scholars have argued that terrorism framed is constructed according to the ideological boundaries and national interest of the country ( $\mathrm{Du} \& \mathrm{Li}, 2017$ ). This interplay of ideology and national interest plays decisive role in deciding how terrorism is to be framed and this is considered the national context which affects reporting and frames of the news stories.

Scholars argue that regional context, in which terrorism is framed, draws its ideological basis from cultural differences and is informed by the controversial idea of "Clash of civilizations" from Samuel P. Huntington (Barber, 1995). Cultural proximity, though not part of Huntington's idea of "clash of civilization", has also been termed as a reason for the regional differences in portrayal of news since much earlier than Huntington's theory or even before the birth of "framing" as one of the dominant theories of media effects (Galtung \& Ruge, 1965). This cultural proximity plays a role in different framing of same news due to the cultural and ideological differences of two culturally distant regions. We see West vs. Arab coverage of terrorism news come under this category and scholars have reported wide ranging differences among how Arab, European, or US news outlets portray and frame different incidents of terrorism. One of the dominant themes "us versus them" can also be categorized under this regional aspect of frames' construction (Axelrod \& Forster, 2017; Fahmy, 2010; Roy \& Ross, 2011).

Global ideological discourses on terrorism are our last theoretical consideration for this study on frame construction. Proponents of this theoretical consideration of framing claim that similarities in global media discourses are an outcome of globalization partly due to increase in formal communication links and mainly because of US dominance of global media discourse (Hafez, 2005; McChesney \& Herman, 2000). (Roy \& Ross, 2012) found out that Indian and US media employed "us vs. them" frame along with global "war on terror" frame while covering Mumbai terror attacks of 2008. Us versus them frame is closely linked with "war on terror" frame where global standardization of "us" as civilized and "them" being the opposite, barbaric, and uncivilized terrorists and a threat to civilized world evokes this idea that India is part of civilized world and reify social identities aligning with US. Global "war on terror(ism)" frame, as (Reese, 2010) described, was conscious construction of Bush administration in order to further its policy of preemptive strike and export wars, has become globalized. Countries around the world and media everywhere have adopted this frame in order to portray any acts of violence within their borders or abroad. Reese claims that there has been minimum to no resistance against Bush administration's policies due to automatic adoption of "war on terror" frame and fear it created among 
US citizens. Other scholars have found out that media around the world have adopted this frame to portray acts of violence (Axelrod \& Forster, 2017; Patrick, 2014; Powell, 2011; Reese, 2010).

Informed by these national, regional, and global theoretical aspects of frame constructions, this study aims to investigate how Chinese, Thai, and US media framed the 10-28 attack in Tiananmen and how frames were locally constructed or borrowed globally. Use of analogies plays an important part in linking the incident/news with previous incidents in history in order to bring salience and make sense of incident and place (Axelrod \& Forster, 2017). Mumbai, for example, is either referred to as city of Indian film industry "Bollywood" or is referred to as a place where the 11-26 terror attacks had happened and it depends solely upon the reporter what analogy S/he would employ in writing a news story about any incident happening in Mumbai. These historical analogies become even more important when analyzing US media coverage of an incident in China since ideological and cultural differences play an important role while mentioning Tiananmen or Beijing in a news story and what kind of analogies are used to refer the place.

\section{Data Selection and Methods}

The process for data collection in this study involved five steps: the selection of event to be analyzed, the selection of publications whose coverage will be used for the selected event, the identification of relevant articles from the newspapers selected, coding of the selected articles from newspapers, and creation of corpora for AntConc software for analysis.

\subsection{Event}

Three family members in a sports vehicle rammed into the pedestrian way on $28^{\text {th }}$ October, 2013, killing 5 including those in the vehicle and injuring 38 other tourists near Tiananmen square in Beijing (Ranran, 2013). This event is popularly referred to as the 10-28 attack in media and research scholarship. We selected the 10-28 as our "event" about which the coverage will be analyzed about frames construction, historical analogies, and concordance.

\subsection{Newspapers}

We selected China Daily (CD) newspaper from China which is national daily English language newspaper of China and has developed into a multimedia platform according to its website (China Daily, 2019). Asia News Monitor is published from Thailand and it is considered Thailand's national English language daily. Asia News Monitor (ANM) publishes news from its reporters and buys from agencies and publishes that news either fully or with contributions from their own staff reports. Asia News Monitor's inclusion for this study serves the purpose to estimate how historical analogies will be used by non-Chinese or non-US newspaper as rest of the newspapers included in this study are from China and US. Asia News Monitor's (ANM) borrowing of frames from Chinese or US me- 
dia can also help in understanding the flow of frames either from national to global or global to regional when assessing the 10-28 event. New York Times and Wall Street Journal from US have been selected for the study. New York Times (NYT) is one of the most prominent US newspapers credited with furthering US foreign policy and is considered among the top newspapers in US with liberal bent (de Vise, 2011). Wall Street Journal, on the other hand, is published by famous Dow Jones Company, a subsidiary of News Corp., and has a conservative bent (Vernon, 2017). Wall Street Journal (WSJ) is considered close to conservative leadership in US and has been accused of siding with Republican Party's stance. Thus, it is important to study both New York Times and Wall Street Journal for the study along with China Daily and Asia News Monitor.

\subsection{Identification of Relevant Articles}

Articles published in four newspapers over the time period of a week were selected at two different levels. Initially, researcher was staying in Beijing at the time of the attack and had followed China Daily and New York Times' coverage of the incident on daily basis while collecting all the relevant articles at that time including pictures and a couple videos which were later taken off from internet by authorities. From October 27 to November 7, 2013, China Daily published a total of 8 articles on Tiananmen Square attack while New York Times had published 5 such articles along with some blog posts under "Sinosphere" blog which was being published in New York Ties at that time. Later on, in order to collect sufficient data and bring in conservative US narrative and Thai narrative to frame construction, ProQuest database was searched for newspaper articles from October 27 to November 7, 2013, exact same dates with the previous data set already available with the researcher. Keywords were used to find news stories published in Wall Street Journal and Asia News Monitor. A combination of two keywords "China" and "attack" returned 145 results from many different news sources. All the results were scanned carefully by researcher himself in order to determine relevant news stories published in Asia News Monitor and Wall Street Journal. Thailand's Asia News Monitor published 8 such news articles about the 10-28 attack and Wall Street Journal had published 12 such news stories over the decided time period. A total of 33 such news articles/stories from all four publications were collected and later coded for analysis. A breakdown of data is also given in Table 1 below.

Table 1. Breakdown of data selected for the study.

\begin{tabular}{ccccc}
\hline & Frequency & Percent & Valid Percent & Cumulative Percent \\
\hline Asia News Monitor & 8 & 24.2 & 24.2 & 24.2 \\
China Daily & 8 & 24.2 & 24.2 & 48.5 \\
New York Times & 5 & 15.2 & 15.2 & 63.6 \\
Wall Street Journal & 12 & 36.4 & 36.4 & 100.0 \\
Total & 33 & 100.0 & 100.0 & \\
\hline
\end{tabular}




\subsection{Coding}

Selected 33 news articles were then coded for analysis according to the coding sheet. A coding sheet was developed consisting 7 different variables. Variables included name of publication, size of story, war on terror frame, depth of coverage, analogies, blame/victimization, and evaluation of the incident. Complete data was coded and typed in SPSS software for analysis using this coding sheet (Annexure). All the text from these 33 news articles was converted into txt files and divided into two different corpora consisting $\mathrm{A} 1$ and $\mathrm{U} 1$ where $\mathrm{A} 1$ contained news texts from China Daily and Asia News Monitor while U1 contained news texts from New York Times and Wall Street Journal. These corpora were then fed into AntConc, a free software for measuring concordance and word association, in order to do further in-depth discursive analysis to check how different frames and analogies with certain word associations were used.

\section{Data Analysis and Results}

After coding of data in SPSS, researcher ran crosstabs in SPSS in order to find out different aspects of framing in the data. Before jumping onto terrorism frame and discussion, it is of the importance to mention the size of the story as it is directly proportionate to depth of coverage, either episodic or thematic. Depth of coverage determines how story has been linked in detail with previous historic incidents to make sense of the current event. There were 7 small or less than 300 words news articles, 14 such news stories were between 300 - 600 words and considered medium sized article, while 12 of the stories published in the newspapers were more than 600 words long and considered large size stories. Following Table 2 shows breakdown of the size of stories published in respective newspapers.

Asia News Monitor only published 5 medium sized and 3 small sized news stories while China Daily published 2 large size and 4 medium sized news stories. Wall Street Journal ended up publishing half of its news about the incident in detail and consisting of more than 600 words.

Presence of "war on terror" frame in news story confirms globalization aspect of news framing theory where according to (Barber, 1995; McChesney \& Herman, 2000) media around the globe have adopted to the unified framing about terrorism but this study revealed that reference to "war on terror (ism)" frame in this case was lacking. Chinese authorities did not call this incident an act of terror until three days later when the attack took place (see Table 3). Only 9 out total 33 news stories employed "war on terror" frame. China Daily refrained from making such references and 7 out of 8 news articles and commentary pieces did not mention war on terror frame but linked the attack with Uyghur ethnic minority in far west of the country. Thus, confirming to the point in previous scholarship that China has always been cautious to support "war on terror" and avoided bringing any social, economic, human, and environmental damage to the outside world (Rahman, 2012). It also confirms that China Daily, instead of 
Table 2. Size of the stories published in respective newspapers.

\begin{tabular}{ccccc}
\hline \multicolumn{3}{c}{ Respective size of stories published in newspapers } \\
\hline \multirow{2}{*}{ Name of the Publication } & \multicolumn{3}{c}{ Size of the Story } & \multirow{2}{*}{ Total } \\
\cline { 2 - 4 } & Small & Medium & Large & \\
\hline Asia News Monitor & 3 & 5 & 0 & 8 \\
China Daily & 2 & 4 & 2 & 8 \\
New York Times & 0 & 3 & 2 & 5 \\
Wall Street Journal & 2 & 2 & 8 & 12 \\
Total & 7 & 14 & 12 & 33 \\
\hline
\end{tabular}

Table 3. War on terror frame presence in news stories.

\begin{tabular}{|c|c|c|c|}
\hline \multicolumn{4}{|c|}{ War on terror frame presence in news } \\
\hline \multirow{2}{*}{ Name of the Publication } & \multicolumn{2}{|c|}{ War on Terror Frame } & \multirow{2}{*}{ Total } \\
\hline & Yes & No & \\
\hline Asia News Monitor & 2 & 6 & 8 \\
\hline China Daily & 1 & 7 & 8 \\
\hline New York Times & 2 & 3 & 5 \\
\hline Wall Street Journal & 4 & 8 & 12 \\
\hline Total & 9 & 24 & 33 \\
\hline
\end{tabular}

borrowing globalized frame, tried to construct nationalistic/local frame for the attack to meet national interest and blamed a whole Uyghur ethnic minority people of Xinjiang.

Use of analogies is one way of constructing the frame and making it "salient" in order for the audiences to remember it compared to other details. Some scholars have proven that newspapers use analogies in wider range for audiences giving less regard to similarity with the incident (Axelrod \& Forster, 2017). This study examined that a total of 45 such instances of usage of a historical analogy were used in those 33 news articles. Use of those historical analogies differed and contrasted a great deal between Asian and US newspapers. China daily either did not use any analogy ( 3 out of 8 ) or used an analogy ( 4 out of 8 articles) linking some past domestic terror incident with the current event. Asia News Monitor on the other hand borrowed an analogy from New York Times and mentioned Tiananmen Square to be part of the 1989 students' pro-democracy protests. Apart from this one reference, Asia News Monitor did employ other analogies in three more articles but made references to some other historical incidents which neither were any protests nor terror attacks. Asia News Monitor on most of the other occasions tried to ascertain credibility through mentioning Chinese authorities and their call for stronger measures to combat terrorism within region (instead of making reference to global war on terror).

New York Times and Wall Street Journal, on the other hand, employed analo- 
gies frequently. 34 out 45 instances of analogies in data were found in US newspapers only (see Table 4). There was only one Wall Street Journal story of less than 200 words where it did not employ an analogy otherwise multiple analogies were used within every single news item. Most of the analogies used by US media (Both NYT and WSJ) in order to bring prominence to the incident were "past freedom/rights movements" instead of linking the attack with global terrorism thus proving the notion of cultural proximity and bias towards non-western countries in covering terrorism as indicated in previous studies (Ismail \& Mishra, 2019; Patrick, 2014; Qi \& Ye, 2019). New York Times and Wall Street Journal's favored analogy in the text was referring Tiananmen to be a place where 1989 pro-democracy student protests had been held and how authorities had quelled the protest. Whenever Wall Street Journal linked the event with previous terror attack, it also mentioned either Tiananmen protest or Xinjiang's historical poverty and exclusion.

Blame or victimization is important frame in order to determine how frames have been borrowed from elsewhere or been formed domestically. Putting blame on global network of terrorists can point out that global war on terror frame has been borrowed in order to make the current incident relevant to global war on terror. While on the other hand, if some local element has been blamed for the incident without connecting it to the bigger "nexus of global terrorism", it can be concluded that frames have been constructed keeping in mind national interest, need, and ideologies. We coded this section of the coding book in four categories. Either there has been no blame sanctioned on any of the actors or Xinjiang people have been blamed for the incident, or Chinese government has been blamed for the incident to have happened or even global terrorism has been held responsible for Tiananmen attack. Data analysis revealed that Chinese media levelled the blame on Xinjiang people and extremist elements were portrayed to be illiterate, barbaric, divorced from reality, and real cause for the Uyghurs' pains. While US media on the other hand either avoided to label the blame on anyone or shared the blame between global terrorism making way into China and China's poor policies and unjust treatment of Uyghur's to be the reason for them to take extremist paths (Table 5).

Table 4. Type and number of analogies used by different newspapers.

\begin{tabular}{|c|c|c|c|c|c|c|}
\hline \multicolumn{7}{|c|}{ Type and number analogies used by newspapers } \\
\hline \multirow[b]{2}{*}{$\begin{array}{l}\text { Name of the } \\
\text { Publication }\end{array}$} & \multicolumn{4}{|c|}{ Analogies } & \multirow[b]{2}{*}{ Total } & \multirow[b]{2}{*}{$\begin{array}{c}\text { Total } \\
\text { Number of } \\
\text { Analogies }\end{array}$} \\
\hline & $\begin{array}{c}\text { No Analogy } \\
\text { Used }\end{array}$ & $\begin{array}{c}\text { Past Terror } \\
\text { Incident }\end{array}$ & $\begin{array}{c}\text { Past } \\
\text { Rights/Freedom } \\
\text { Movement }\end{array}$ & $\begin{array}{l}\text { Other } \\
\text { Historical } \\
\text { References }\end{array}$ & & \\
\hline Asia News Monitor & 4 & 0 & 1 & 3 & 8 & 4 \\
\hline China Daily & 3 & 4 & 0 & 1 & 8 & 7 \\
\hline New York Times & 0 & 2 & 1 & 2 & 5 & 12 \\
\hline Wall Street Journal & 1 & 5 & 5 & 1 & 12 & 22 \\
\hline Total & 8 & 11 & 7 & 7 & 33 & 45 \\
\hline
\end{tabular}


Table 5. US media blames China's poor treatment of Xinjiang region to be root cause for extremism.

\begin{tabular}{|c|c|c|c|c|c|}
\hline \multicolumn{6}{|c|}{ Who is blamed for the incident by news story } \\
\hline \multirow[b]{2}{*}{ Name of the Publication } & \multicolumn{4}{|c|}{ Blame/Victimization } & \multirow[b]{2}{*}{ Total } \\
\hline & No Blame & $\begin{array}{c}\text { Xinjiang } \\
\text { Muslims Blamed }\end{array}$ & $\begin{array}{l}\text { China } \\
\text { Government }\end{array}$ & $\begin{array}{c}\text { Global } \\
\text { Terrorism }\end{array}$ & \\
\hline Asia News Monitor & 1 & 4 & 2 & 1 & 8 \\
\hline China Daily & 1 & 5 & 0 & 2 & 8 \\
\hline New York Times & 3 & 0 & 0 & 2 & 5 \\
\hline Wall Street Journal & 2 & 4 & 4 & 2 & 12 \\
\hline Total & 7 & 13 & 6 & 7 & 33 \\
\hline
\end{tabular}

Wall Street Journal on many occasions while talking about Tiananmen incident, brought up Xinjiang's poor people and new job opportunities going to Han Chinese while Uyghur people were quoted to be fearful of losing their cultural identity in the region while being assimilated to mainstream. Similarly, most of Wall Street Journal stories were detailed and contained more than 600 words providing a thematic frame of the Uyghur problem instead of labelling them responsible for the attack and sympathized by portraying such attacks as acts of defiance rather than terrorism.

Since US media, especially Wall Street Journal, portrayed Uyghurs as persecuted community and avoided blaming them for the attack and blamed Chinese policies instead to have caused such violent reactions, it is also found out that evaluation of the incident by Chinese, Thai, and US newspapers also differs from each other. Researcher had coded six different evaluations of the incident being reported. Evil terrorists meant that story portrayed extremists as evil and barbaric but did not connect them global terrorism. Diplomacy versus terrorism frame evaluation meant that newspaper either presented the incident as failure of the state efforts to take perpetrators into confidence and as a failure of diplomacy. Freedom struggle/movement evaluation meant that newspapers tried to portray the incident as an act of defiance by people vying for freedom from a state. Extremist vs. Sufi Muslim evaluation meant that newspapers might have portrayed Sufi tradition of Uighur Muslims who follow non-violent Sufi branch of Islam and could not have been radical and extremists, hinting that it was failure if the state to have forced them to retort to violent ways. Global terror vs. sole act of terror evaluation portrays that this incident is not part of global terrorist network but an act of revenge or defiance by a sole individual or group of individuals (see Table 6). It is interesting to see that China daily, Chinese newspaper considered as government's mouth piece, evaluated the incident as evil terrorists but did not connect it with global terrorism network although one of the officials in one news item was quoted asking for regional efforts to curb terrorism. Asia News Monitor, on the other hand, 5 out of 8 times evaluated the incident as sole act of violence instead of borrowing NYT, WSJ, or China Daily's evaluations. 
Table 6. China Daily evaluated the attack as evil terrorists and accused Xinjiang people of the attack.

\begin{tabular}{|c|c|c|c|c|c|}
\hline \multicolumn{6}{|c|}{ How the incident has been evaluated } \\
\hline \multirow[b]{2}{*}{ Evaluation } & \multicolumn{4}{|c|}{ Name of the Publication } & \multirow[b]{2}{*}{ Total } \\
\hline & $\begin{array}{l}\text { Asia News } \\
\text { Monitor }\end{array}$ & China Daily & $\begin{array}{c}\text { New York } \\
\text { Times }\end{array}$ & $\begin{array}{c}\text { Wall Street } \\
\text { Journal }\end{array}$ & \\
\hline Evil Terrorists & 2 & 7 & 0 & 3 & 12 \\
\hline Diplomacy vs. Terrorism & 0 & 0 & 1 & 0 & 1 \\
\hline Freedom Struggle/Movement & 0 & 0 & 1 & 2 & 3 \\
\hline Extremist vs. Sufi Muslim Uyghurs & 1 & 0 & 0 & 1 & 2 \\
\hline Global Terror vs. Sole Act of Violence & 5 & 0 & 3 & 1 & 9 \\
\hline No Evaluation & 0 & 1 & 0 & 5 & 6 \\
\hline Total & 8 & 8 & 5 & 12 & 33 \\
\hline
\end{tabular}

\section{Conclusion}

Informed by the national, regional, and globalized framing construction practices, this study attempted to make sense of the 10-28 Tiananmen attack in 2013 through analyzing news stories from Asia News Monitor, China Daily, New York Times, and Wall Street Journal. Data analysis and findings reveal that national interests, ideologies and cultural boundaries play comparatively more important part in constructing frames although there were instances of frames borrowing recorded especially by Asia News Monitor, the Thailand newspaper. It was also found out that US media has somewhat bias towards China when reporting any violence or terrorist attacks. US media employs persecution and poverty frames for ethnic minorities in order to make them look justified in their acts of violence. Analogies used by US media do not relate to nature of the attack but US media found a way to mention Tiananmen as a site for resistance instead of a place under attack from extremists. Whenever Wall Street Journal, for example, mentioned terrorism frame in its stories, it soon brought up Uyghur persecution and insensitivity of Chinese authorities towards ethnic Uyghurs. It displayed their identity and culture as being threatened and in a way justified their attack as an act of desperation.

China Daily constructed its own frames and evaluated the incident as evil terrorists against the civilized mainland and development of ethnic regions. China Daily actually restrained from calling this attack as terrorism initially and started calling it terrorism only after three days of the attack. But it did not connect the incident with global terrorism network and neither did employ "war on terror" frame to gain support from outside world. Although, we saw some exchange of frames from global to regional, and national to regional when Asia News monitor borrowed frames from both Chinese Xinhua and US Voice of America news agencies and called this attack terrorism only when Chinese authorities claimed but then went on to employ global "war on terror" frame. So, it can be concluded 
that frames are always at play and news organizations, reporters, and editors employ them or construct on the basis of needs of the hour. Global "war on terror" frame is mostly used to gain acceptance and become part of "us" and gain global acceptance for taking action against "them" the barbaric terrorists. But national interests and ideologies play bigger part in construction of frames while reporting an event.

\section{Conflicts of Interest}

The author declares no conflicts of interest regarding the publication of this paper.

\section{References}

Axelrod, R., \& Forster, L. (2017). How Historical Analogies in Newspapers of Five Countries Make Sense of Major Events: 9/11, Mumbai and Tahrir Square. Research in Economics, 71, 8-19. https://doi.org/10.1016/j.rie.2016.08.001

Barber, B. (1995). Jihad vs. McWorld. How Globalism and Tribalism Are Reshaping the World. New York: Ballantine Books.

China Daily (2019). About China Daily. [Newspaper] http://www.chinadaily.com.cn/e/static_e/about

D’Angelo, P., \& Kuypers, J. A. (2010). Doing News Framing Analysis: Empirical and Theoretical Perspectives. New York: Routledge. https://doi.org/10.4324/9780203864463

de Vise, D. (2011). What if the Rankers Ranked Newspapers? [Newspaper]. https://www.washingtonpost.com/blogs/college-inc/post/what-if-the-rankers-ranked-n ewspapers/2011/10/04/gIQAYZl6KL_blog.html

Du, Y. R., \& Li, L. (2017). When Press Freedom Meets National Interest: How Terrorist Attacks Are Framed in the News in China and the US. Global Media and China, 2, 284-302. https://doi.org/10.1177/2059436418755761

Entman, R. M. (1993). Framing: Towards Clarification of a Fractured Paradigm. Journal of Communication, 43, 51-58. https://doi.org/10.1111/j.1460-2466.1993.tb01304.x https://www.attorneygeneral.jus.gov.on.ca/inquiries/cornwall/en/hearings/exhibits/Ma ry_Lynn_Young/pdf/05_Entman.pdf

Fahmy, S. (2010). Contrasting Visual Frames of Our Times: A Framing Analysis of English- and Arabic-Language Press Coverage of War and Terrorism. International Communication Gazette, 72, 695-717. https://doi.org/10.1177/1748048510380801

Galtung, J., \& Ruge, M. H. (1965). The Structure of Foreign News. The Presentation of the Congo, Cuba and Cyprus Crises in four Norwegian Newspapers. Journal of Peace Research, 2, 64-91. https://doi.org/10.1177/002234336500200104

Gerhards, J., \& Schäfer, M. S. (2014). International Terrorism, Domestic Coverage? How Terrorist Attacks Are Presented in the News of CNN, Al Jazeera, the BBC, and ARD. International Communication Gazette, 76, 3-26. https://doi.org/10.1177/1748048513504158

Hafez, K. (2005). Globalization, Regionalization, and Democratization: The Interaction of Three Paradigms in the Field of Mass Communication. In R. A. Hacket, \& Y. Zhao (Eds.), Democratizing Global Media: One World, Many Struggles (pp. 145-163). Lanham: Rowman and Littlefield Publishers. 
Ismail, A., \& Mishra, S. (2019). Configuring Terrorism in the Age of ISIS: The New York Times' Coverage of the 2015 Beirut and Paris Attacks. Global Media and Communication, 15, 177-193. https://doi.org/10.1177/1742766519846643

McChesney, R. W., \& Herman, E. S. (2000). The Global Media. In D. Held, \& A. McGrew (Eds.), The Global Transformations Reader (pp. 216-229). Cambridge: Polity Press.

Norris, P., Kern, M., \& Just, M. (2003). Framing Terrorism. In P. Norris, M. Kern, \& M. Just (Eds.), Framing Terrorism: The Government, the News Media, and the Public (pp. 1-17). https://doi.org/10.4324/9780203484845

https://sites.hks.harvard.edu/fs/pnorris/Acrobat/Framing\%20terrorism/Chapter\%201\% 20Introduction.pdf

Patrick, S. M. (2014). Framing Terrorism: Geography-Based Media Coverage Variations of the 2004 Commuter Train Bombings in Madrid and the 2009 Twin Suicide Car Bombings in Baghdad. Critical Studies on Terrorism, 7, 379-393.

https://doi.org/10.1080/17539153.2014.957009

Powell, K. A. (2011). Framing Islam: An Analysis of U.S. Media Coverage of Terrorism Since 9/11. Communication Studies, 62, 90.

https://search.proquest.com/docview/849233433?accountid=11524

https://doi.org/10.1080/10510974.2011.533599

Qi, H., \& Ye, F. (2019). Contrastive Analysis of Discursive Constructions in Terrorist Attack Reports between Chinese and British Newspapers: Case Study of Reports on Beijing and Barcelona Terrorist Attacks. Journal of Quantitative Linguistics, 1-18. https://doi.org/10.1080/09296174.2019.1595901

Rahman, K. (2012). The Challenge of Terrorism and War on Terror: Chinese Response. Policy Perspectives, 9, 1-16.

Ranran, L. (2013). 5 Dead, 38 Injured after Car Crash at Tian'anmen [Official]. http://english.cri.cn/6909/2013/10/28/2821s794650.htm

Reese, S. D. (2010). Finding Frames in a Web of Culture; The Case of the War on Terror. In P. D’Angelo, \& J. A. Kuypers (Eds.), Doing News Framing Analysis: Empirical and Theoretical Perspectives (pp. 17-42). New York: Taylor and Francis.

Roy, S., \& Ross, S. D. (2011). The Circle of Terror: Strategic Localizations of Global Media Terror Meta-Discourses in the US, India and Scotland. Media, War \& Conflict, 4, 287-301. https://doi.org/10.1177/1750635211420631

Roy, S., \& Ross, S. D. (2012). The Gaze of the US and Indian Media on Terror in Mumbai: A Comparative Analysis. In I. S. Shaw, J. Lynch, \& R. A. Hacket (Eds.), Expanding Peace Journalism: Comparative and Critical Approaches (pp. 191-216). Sydney, Australia: Sydney University Press.

Vernon, P. (2017). Unpacking WSJ's “Watershed” Trump Editorial. https://www.cjr.org/business_of_news/wsj_trump_editorial_opinion.php 


\section{Annexure: Coding Book}

\begin{tabular}{llll}
\hline & Coding Sheet & & Instructions \\
\hline News Stories & & Categories with Assigned Codes & Codes \\
\hline
\end{tabular}

ANM (Asia News Monitor) 1
Name of
the Publication

CD (China Daily) 2

NYT (New York Times) 3

WSJ (Wall Street Journal) 4

Small $\mathrm{X} \leq 300$ words ... 1

2 Size of the Story
Medium $300<\mathrm{X}<600$ words ... 2

Large $\mathrm{X}>600$ words ... 3
Write number assigned to the publication i.e. 2 = China Daily.

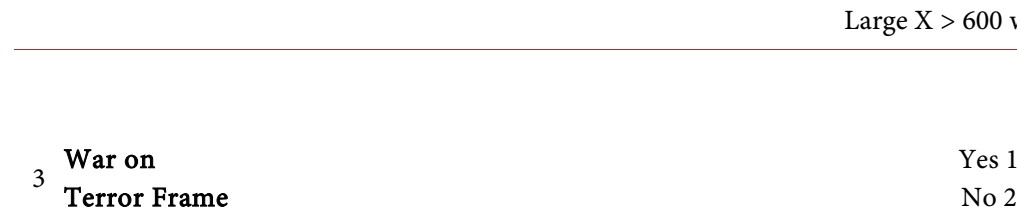

Write number for small, medium, or large story.

If "War on terror" frame as a global effort against terrorism was initiated by US government and was adopted by rest of the world to combat violence within is present in the story?

If the story narrates what happened or uses dramatic adjectives only then it's

4 Depth of Coverage episodic if it connects the incident with past stories and incidents then it must be coded thematic.
Episodic 1

Thematic 2

To be decided on above given definitions and coded by coder.
If the incident has historically been

5 Analogies linked with some previous incident i.e. $9 / 11$.
No Analogy/Historical Context 1

Past Terror Incident 2

Past Rights Movement 3

Other Historical Incident 4

Either Xinjiang people or Chinese government or Global terrorism is

6lame/

Victimization of the Incident blamed for the incident. If the blame has been neutralized between two of the actors then it should be coded as to first actor named in the article.

Coder will see if some kind of Evaluation frame has been used in the story in order to determine the motive of the attack and whether the attack has been condemned as terrorism or approved by the article as an act of resistance.

\section{No Blame 1}

Xinjiang People blamed 2

China Government

Policies in Xinjiang 3

Global Terrorism 4

Evil Terrorists 1

Diplomacy vs. Terrorism 2

Freedom Movement 3

Extremist vs. Sufi Muslim Uyghurs 4

Global Terror vs. Sole Act of Violence 5

Resistance to Unfair Policies 6
Number of Analogies used should also be recorded.

If anyone has been blamed in the story for causing the incident. 